\title{
Binding specificity and intramolecular signal transmission of uncleaved insulin proreceptor in transformed lymphocytes from a patient with extreme insulin resistance
}

\author{
T.Sasaoka ${ }^{1}$, Y.Shigeta ${ }^{1}$, Y.Takata ${ }^{1}$, M.Sugibayashi ${ }^{1}$, A. Hisatomi ${ }^{2}$ and M.Kobayashi ${ }^{1}$ \\ ${ }^{1}$ The Third Department of Medicine, Shiga University of Medical Science, Ohtsu, Shiga, and \\ ${ }^{2}$ Diabetes Center, Kokura City Hospital, Kitakyusyushi, Japan
}

\begin{abstract}
Summary. An alteration of an amino acid sequence in the processing site of the insulin proreceptor by a point mutation of the insulin receptor gene produced extreme insulin resistance. We characterized functional properties of the unprocessed insulin receptor in transformed lymphocytes from a patient. Insulin binding to intact cells and to a partially purified insulin receptor preparation was radically decreased to $20 \%$ and $18 \%$ of the control values, respectively. In competitive insulin binding to intact cells, $\left[\mathrm{Leu}^{\mathrm{A} 3}\right]-$, $\left[\mathrm{Leu}^{\mathrm{B} 24}\right]-,\left[\mathrm{Ser}^{\mathrm{B} 24}\right]$-insulin, and mini-proinsulin ([B(1-29)-Ala-Ala-Lys-A(1-21)]-insulin) had the same relative binding activity in both the patient's and the control cells, but proinsulin and IGF-I were markedly less able to displace ${ }^{125} \mathrm{I}$-insulin in the patient's cells. In contrast to the study in intact cells, proinsulin and IGF-I as well as other insulin analogues had the same relative binding activity to bind to the partially lectin-purified insulin receptor prepara-
\end{abstract}

tions from both the patient's and the control cells. As regards the signal transduction after receptor binding, insulin-stimulated autophosphorylation of the unprocessed insulin proreceptor occurred proportionally to the amount of decreased insulin binding. With $0.025 \%$ trypsin treatment, the abnormal binding characteristics and autophosphorylation were normalized through conversion to functionally normal receptors. In spite of the abnormal processing, self-association of receptors into oligomeric structures was observed in the proreceptor. These results suggest that the unprocessed insulin proreceptor in the plasma membranes has an altered conformation which affects its binding characteristics but not its intramolecular signal transmission.

Key words: Insulin receptor, insulin proreceptor, insulin resistance, transformed lymphocytes, point mutation.
Insulin initiates its cellular response by binding to the insulin receptor $[1,2]$. Thus, a primary defect in insulin receptors leads to extreme insulin resistance as demonstrated in type A insulin resistance [3-14], leprechaunism $[4,6,7,11,14-24]$, and Rabson-Mendenhall syndrome [14, 25-27]. Recently, we [28, 29] and Kakehi et al. [30] reported a patient with type A extreme insulin resistance due to abnormal processing of the insulin proreceptor. Subsequently, DNA sequencing of the interconnecting region between alpha- and beta-subunits revealed $\mathrm{G} \rightarrow$ T point mutation which changed -Arg-LysArg-Arg- to -Arg-Lys-Arg-Ser- [31, 32]. The Arg $\rightarrow$ Ser structural change appeared to be the cause for abnormal processing of the insulin proreceptor. However, attention has been focused on the mechanism of abnormal processing of the proreceptor in the previous studies [28-32], and functional properties of the unprocessed insulin proreceptor itself have not been investigated in detail. Since insulin binding was markedly decreased, hormone binding specificity and intramolecular signal transmission may also undergo a change by structural alteration due to abnormal processing of the insulin proreceptor.

Therefore, in the present study, we attempted to characterize the structural alteration of binding sites of the unprocessed insulin proreceptor by examining the binding properties by using various insulin analogues in intact cells and partially lectin-purified insulin receptor preparations. Furthermore, we examined whether selfassociation of the receptors into the oligomeric structure occurred in the proreceptor. Finally, we investigated kinase activity of the proreceptor to study whether the structural change could alter intramolecular signal transmission between alpha- and beta-subunits.

\section{Subjects and methods}

Two sisters, 27 (patient 1) and 23 (patient 2) years old, were products of consanguineous marriage (nephew-niece) and had been born after full-term uncomplicated pregnancy and delivery. Birth weights were $1,800 \mathrm{~g}$ (patient 1) and 1,750 g (patient 2). At birth, they were noted to be hirsute. Their growth has been retarded since infancy. At the age of 


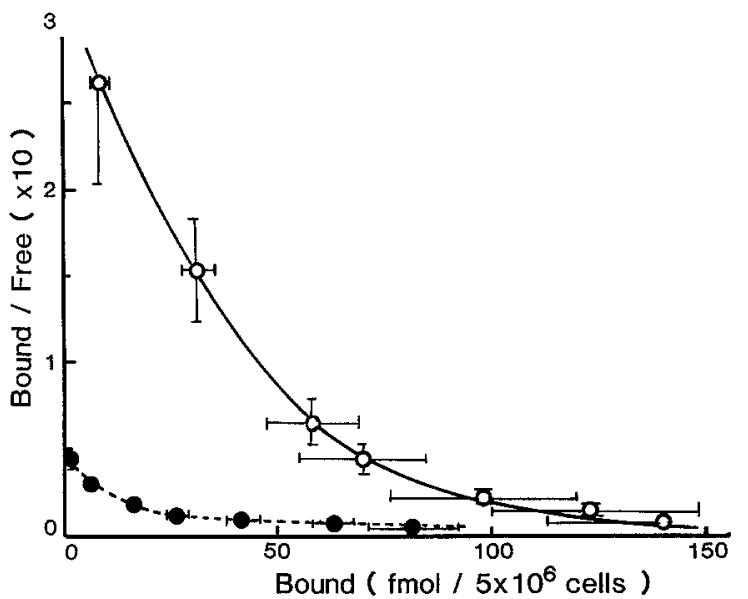

Fig.1. Scatchard analysis of insulin binding. Transformed lymphocytes were incubated with ${ }^{125} \mathrm{I}$-insulin $(0.2 \mathrm{ng} / \mathrm{ml})$ and various concentrations of unlabelled insulin at $15^{\circ} \mathrm{C}$ for $3.5 \mathrm{~h}$. Scatchard analysis of insulin binding data was expressed as means \pm SEM of 5 separate experiments for both the control subjects $\left(\mathrm{O}_{-} \mathrm{O}\right)$ and the patient $(\odot--)$

10 (patient 1) and 6 (patient 2) years, they were diagnosed with diabetes mellitus. Current status included presentation with primary amenorrhea for both women. Patient 2 had suffered from bronchial asthma and had been treated with steroids since three months of age, but past history was otherwise unremarkable. There was no history of diabetes mellitus in other family members. On physical examination, patient 1 was $128 \mathrm{~cm}$ tall and weighed $35 \mathrm{~kg}$, and patient 2 was $133 \mathrm{~cm}$ tall and weighed $36 \mathrm{~kg}$. They had apathetic faces, saddle noses, odontodysplasia, abdominal distention, generalized hirsutism, and acanthosis nigricans in the neck and the axillae. Their external genital were normal. They had mental retardation marked in patient 1 and mild in patient 2. Ophthalmoscopic examination revealed proliferative retinopathy with retinal detachment in patient 1 and background retinopathy in patient 2 . Routine laboratory tests at the time of admission were normal except for glucose metabolism. Oral glucose tolerance tests revealed diabetic patterns in both patients. Fasting blood glucose levels ranged from 7.0 to $12.0 \mathrm{mmol} / 1$ in patient 1 and from 4.6 to $7.2 \mathrm{mmol} / 1$ in patient 2 . Serum insulin levels were $286-351 \mu \mathrm{U} / \mathrm{ml}$ in patient 1 and $242-312 \mu \mathrm{U} / \mathrm{ml}$ in patient 2 at fasting, and $978 \mu \mathrm{U} / \mathrm{ml}$ in patient 1 and $1421 \mu \mathrm{U} / \mathrm{ml}$ in patient 2 at maximum. An i.v. bolus of exogenous insulin $(0.1 \mathrm{U} / \mathrm{kg})$ decreased initial blood glucose levels by 18 and $15 \%$ at 60 min after injection. Neither anti-insulin nor anti-insulin receptor antibody was detectable. Urinary glucose was between $77-100 \mathrm{~g} /$ day in patient 1 and was not detected in patient 2 . Endocrine studies revealed normal values of plasma growth hormone, thyroid stimulating hormone, $T_{3}, T_{4}$, cortisol, and glucagon in both the patients. In spite of normal estradiol and estriol levels in both patients estrone levels were elevated to 65.5 and $159 \mathrm{pg} / \mathrm{ml}$ (normal, $10-60 \mathrm{pg} / \mathrm{ml}$ ), respectively. Testosterone and androstenedione levels were within normal range in patient 1 and were elevated to $2.9 \mathrm{ng} / \mathrm{ml}$ (normal, $0.66-1.95 \mathrm{ng} / \mathrm{ml}$ ) and $5.3 \mathrm{ng} / \mathrm{ml}$ (normal, $0.5-2.4 \mathrm{ng} / \mathrm{ml}$ ) in patient 2. Serum luteinizing hormone ( $\mathrm{LH})$ and follicular stimulating hormone (FSH) levels responded normally to luteinizing hormone releasing hormone stimulation in patient 1 . However, stimulated LH level was high, and the response of FSH was normal in patient 2 . CT scan and ultrasonography revealed normal findings in patient 1 , but showed the bilateral polycystic ovary in patient 2 . Patient 1 was treated with metformin and glibenclamide, and $\mathrm{HbA}_{1}$ improved from 10.1 to $8.6 \%$. Glucose control in patient 2 was relatively good with diet only. Insulin binding to their erythrocytes was decreased to 26 and $32 \%$ of control value, respectively, as previously described [28], and insulin binding to erythrocytes from their mother also mildly decreased to $68 \%$. The details of glucose and insulin levels of the parents was not available because of their lack of cooperation in the study. The informed consent for this study was obtained from the patients, and our studies on these patients were approved by the ethical committee at Shiga University of Medical Science.

\section{Materials}

Purified porcine insulin, human proinsulin, and recombinant derived human IGF-I were a gift from Shimizu Pharmaceutical Co. (Shizuoka, Japan), Shionogi Pharmaceutical Co. (Osaka, Japan), Fujisawa Pharmaceutical Co. (Osaka, Japan), respectively. Semisynthesis of human $\left[\mathrm{Leu}^{\mathrm{A} 3}\right]-[33]$, [Leu $\left.{ }^{\mathrm{B} 24}\right]-[34]$, and $\left[\mathrm{Ser}^{\mathrm{B} 24}\right]-[35]$, and mini-proinsulin ([B(1-29)-Ala-Ala-Lys-A(1-21)]-insulin) [36] was previously described. $\mathrm{Na}\left[{ }^{125} \mathrm{I}\right]$ and [gamma- $\left.{ }^{32} \mathrm{P}\right] \mathrm{ATP}(1000-3000 \mathrm{Ci} / \mathrm{mmol})$, were purchased from New England Nuclear (Boston, Mass, USA). RPMI 1640 medium, fetal bovine serum (FBS), and trypsin were from Gibco Biological Co. (Grand Island, NY, USA). Fatty acid free bovine serum albumin (BSA) and polyethylene glycol (Mr:8000) were from Sigma Chemical Co. (St.Louis, MO, USA). Disuccinimidyl suberate (DSS) was from Pierce-Chemical Co. (Rockford, Ill, USA). Protein A (Pansorbin) was from Calbiochem-Behring Co. (La Jolla, Calif, USA). Wheat germ agglutinin (WGA) agarose was from Pharmacia PL Biochemical Co. (Uppsala, Sweden). All other reagents were of analytical grade.

\section{Iodination of insulin}

${ }^{125}$ I-insulin was prepared by the method of Freychet et al. [2] using chloramine $\mathrm{T}$ to a specific activity of $70-120 \mu \mathrm{Ci} / \mathrm{ug}$. Subsequently, the iodinated insulin was purified by Biogel P-30 (Biorad Laboratories. Richmond, Calif, USA).

\section{Transformed lymphocytes culture}

Epstein-Barr virus transformed lymphocyte cell lines, established from peripheral blood lymphocytes as described previously from the patients and six normal subjects, were grown in RPMI 1640 medium supplemented with 10\% FBS [27]. Since two cell lines from the sisters showed extremely low insulin binding [28], the following characterization of the insulin receptor was performed only in the cells from patient 2 .

\section{Insulin binding to intact cells}

${ }^{125}$ I-insulin binding to transformed lymphocytes has been described elsewhere [4]. Binding studies were carried out at $15^{\circ} \mathrm{C}$ for $3.5 \mathrm{~h}$. In all binding studies, non-specific binding was less than $12 \%$ of the total bound, and degradation of ${ }^{125} \mathrm{I}$-insulin in the buffer was assessed by precipitation with $7.5 \%$ trichloroacetic acid (TCA), and was less than $7 \%$.

\section{Preparation of partially purified insulin receptor}

Transformed lymphocytes $\left(>5 \times 10^{8}\right.$ cells) were washed with phosphate-buffered saline (PBS) and solubilized in a solution of $50 \mathrm{mmol} / \mathrm{l}$ Hepes buffer containing $1 \%$ Triton X-100, 2 mmol phenylmethyl sulfonyl fluoride, and $1 \mu \mathrm{g} / \mathrm{ml}$ aprotinin, $\mathrm{pH}$ 7.6. The cell extract was then stirred at $4^{\circ} \mathrm{C}$ for $60 \mathrm{~min}$. After removing insoluble material by centrifugation at $200,000 \times g$ for $60 \mathrm{~min}$, supernatants were applied to a WGA-agarose column. After extensive washing with a buffer containing $50 \mathrm{mmol} / 1 \mathrm{Hepes}, 150 \mathrm{mmol} / 1 \mathrm{NaCl}$, and $0.1 \%$ Triton $\mathrm{X}-100$, pH 7.4, glycoprotein-enriched preparations were eluted by a buffer containing $0.3 \mathrm{mnol} / 1 \mathrm{~N}$-Acetyl-D-glucosamine in $50 \mathrm{mmol} / 1$ Hepes, $150 \mathrm{mmol} / 1 \mathrm{NaCl}$, and $0.1 \%$ Triton X-100, $\mathrm{pH} 7.6[10]$. 


\section{Insulin binding to lectin-purified insulin receptor preparations}

Lectin-purified receptors were incubated with ${ }^{125} I$-insulin $(0.4 \mathrm{ng} / \mathrm{ml})$ and various concentrations of unlabelled peptides at $4^{\circ} \mathrm{C}$ for $16 \mathrm{~h}$. Bound insulin was separated from the free insulin by precipitation with polyethylene glycol at a final concentration of $12.5 \%$, using $0.1 \mathrm{mg} / \mathrm{ml}$ of bovine gamma-globulins as carrier.

\section{Affinity cross-linking studies}

Affinity labelling was performed by previously published methods with some modifications [37]. The lectin-purified extracts were incubated with ${ }^{125} \mathrm{I}$-insulin $(1 \mathrm{ng} / \mathrm{ml})$ in a buffer containing $120 \mathrm{mmol} / 1$ $\mathrm{NaCl}, 2.5 \mathrm{mmol} / 1 \mathrm{KCl}, 1.2 \mathrm{mmol} / 1 \mathrm{MgSO}_{4}, 15 \mathrm{mmol} / 1 \mathrm{Na}$-acetate, $10 \mathrm{mmol} / \mathrm{l}$ glucose, $1 \mathrm{mmol} / 1$ EDTA, $50 \mathrm{mmol} / 1$ Hepes, and $1 \%$ BSA, pH 7.8, at $4^{\circ} \mathrm{C}$ for $16 \mathrm{~h}$, and cross-linked with $0.1 \mathrm{mmol} / 1$ DSS. After incubation at $4^{\circ} \mathrm{C}$ for $20 \mathrm{~min}$, the cross-linking reaction was stopped by the addition of Tris $(10 \mathrm{mmol} / \mathrm{l}) /$ EDTA $(1 \mathrm{mmol} / \mathrm{l})$ in PBS.

\section{Autophosphorylation assays}

The lectin-purified extracts were preincubated with various concentrations of insulin at $4^{\circ} \mathrm{C}$ for $16 \mathrm{~h}$. The phosphorylation reaction was initiated by adding a solution composed of $20 \mathrm{mmol} / 1$ Mn acetate, $5 \mathrm{mmol} / 1$ cytidine triphosphate, $20 \mu \mathrm{mol} / 1 \mathrm{ATP}$, and $30 \mu \mathrm{Ci}$ of [gamma- ${ }^{32} \mathrm{P}$ ]ATP. After incubation at $4^{\circ} \mathrm{C}$ for $10 \mathrm{~min}$, the reaction was terminated by adding stopping solution containing $0.2 \%$ Triton X-100, $10 \mathrm{mmol} / 1$ EDTA, $100 \mathrm{mmol} / 1 \mathrm{NaF}, 20 \mathrm{mmol} / 1$ sodium pyrophosphate, $20 \mathrm{mmol} / \mathrm{l} \mathrm{ATP}$, and $20 \mathrm{mmol} / \mathrm{l}$ Hepes, $\mathrm{pH} 7.6[10]$.

\section{Immunoprecipitation of insulin receptors}

Receptors were incubated for $16 \mathrm{~h}$ at $4^{\circ} \mathrm{C}$ with anti-insulin receptor serum or normal human serum. Immune complexes were precipitated by addition of a $10 \%$ suspension of Pansorbin. After incubation for $2 \mathrm{~h}$ at $4^{\circ} \mathrm{C}$, the immune complexes bound to Pansorbin were sedimented by centrifugation at $10,000 \times g$ for $10 \mathrm{~min}$. After washing, the pellet was dissolved in the Laemmli buffer containing $2 \%$ sodium dodecyl sulfate (SDS), $10 \%$ glycerol, $0.01 \%$ bromophenol blue, and $10 \mathrm{mmol} / 1$ sodium phosphate with or without $100 \mathrm{mmol} / 1$ dithiothreitol (DTT) and boiled for $5 \mathrm{~min}$ and used for SDS-polyacrylamide gel electrophoresis (SDS-PAGE) [10].

\section{Electrophoresis}

Electrophoretic separation of the labelled components in $7.5 \%$ or 4-12 linear gradient polyacrylamide gels was performed as previously described [38]. The phosphorylated proteins were detected by autoradiography of the stained and dried gels on Kodak X-Omat AR film (Kodak Co. Tokyo, Japan) with intensifying screen. The specific bands were excised from the gel and the radioactivity was quantitated by liquid scintillation counting.

\section{Statistical analysis}

Statistical analysis was performed using the Student's $t$-test to analyse the significant differences.

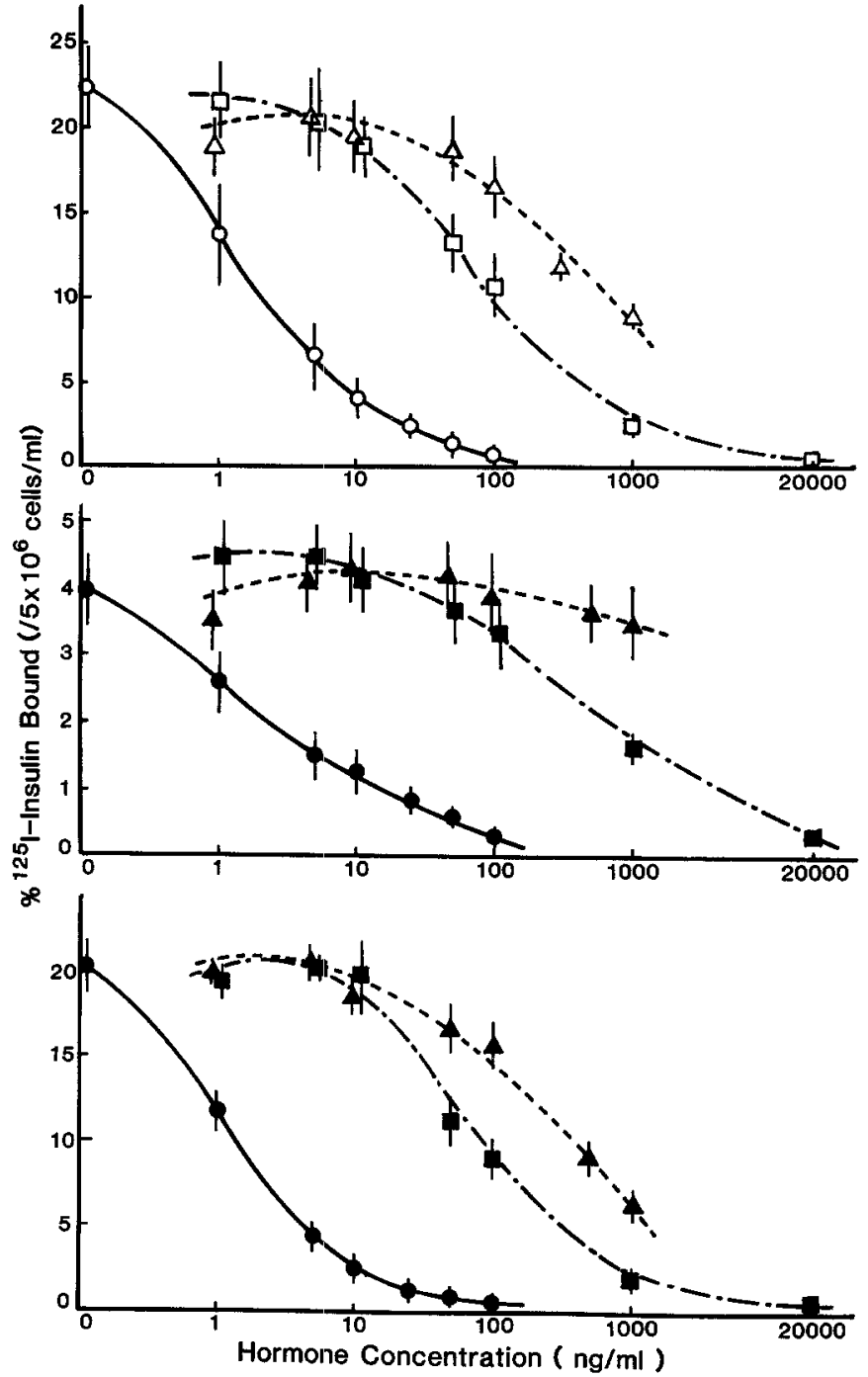

Fig. 2. Competitive binding ability of proinsulin and IGF-I in intact cells. Transformed lymphocytes from normal subjects (top) were incubated with ${ }^{125} \mathrm{I}$-insulin $(0.2 \mathrm{ng} / \mathrm{ml})$ and various concentrations of unlabelled insulin $(O-O,-\longrightarrow)$, proinsulin $(\square--\square, \square---\square)$, or

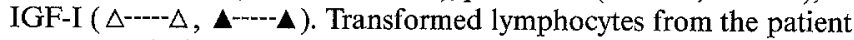
were treated without (middle) or with (bottom) $0.025 \%$ trypsin at $25^{\circ} \mathrm{C}$ for $5 \mathrm{~min}$, followed by the binding studies as described in Methods. Results are means \pm SEM of 5 experiments for both the control subjects and the patient

\section{Results}

\section{Insulin binding to transformed lymphocytes}

Insulin binding to transformed lymphocytes from the patient was markedly decreased to $20 \%$ of that of normal control subjects. Scatchard analysis revealed that low insulin binding in the patient was due to decreased affinity and that receptor number was not decreased (Fig. 1).

\section{Competitive binding ability of proinsulin and IGF-I in intact cells}

To characterize insulin binding to the unprocessed insulin proreceptor, various insulin analogues were tested in binding studies. Figure 2 shows the competitive bind- 

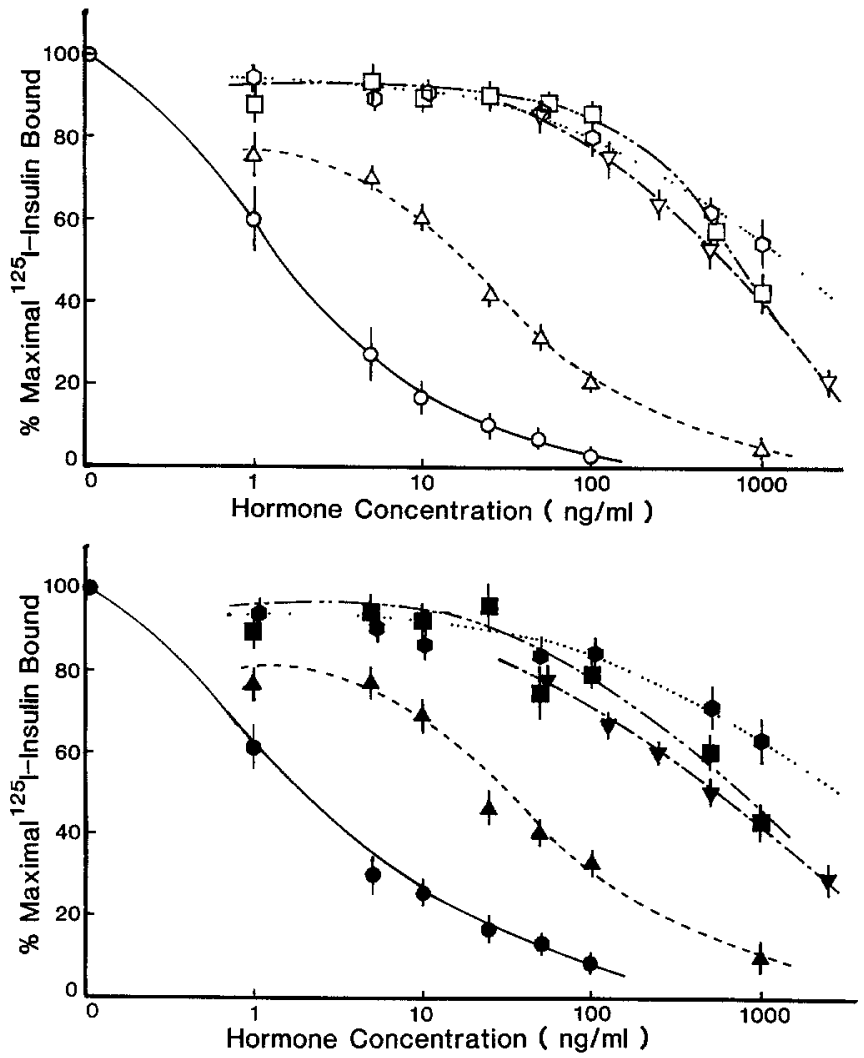

Fig.3. Competitive binding ability of mutant insulins in intact cells. Transformed lymphocytes from the normal subjects (upper panel) and the patient (lower panel) were incubated with ${ }^{125} \mathrm{I}$-insulin $(0.2 \mathrm{ng} / \mathrm{ml})$ and various concentrations of unlabelled insulin $\left(\mathrm{O}_{-} \mathrm{O},-\right.$ $\left[\mathrm{Leu}^{\mathrm{A} 3}\right]-(\square--\square, \mathbf{\square}),\left[\mathrm{Leu}^{\mathrm{B} 24}\right]-\left(\Delta^{-\cdots} \Delta, \mathbf{A}^{-\cdots-1}\right),\left[\mathrm{Ser}^{\mathrm{B} 24}\right]$ $(\triangleleft \cdots, \leftarrow \rightarrow \rightarrow)$ insulin, and mini-proinsulin $(0 \cdots 0, \bullet \cdots)$ at $15^{\circ} \mathrm{C}$ for $3.5 \mathrm{~h}$. Results are means $\pm \mathrm{SEM}$ of percentage of maximal specific ${ }^{125}$ I-insulin binding for 5 experiments for both the control subjects and the patient

ing studies of proinsulin and IGF-I. In transformed lymphocytes from normal subjects, the competitive ability to bind to receptors are $2.20 \%$ and $0.28 \%$ of normal insulin, respectively. In transformed lymphocytes from the patient, however, the competitive ability of proinsulin and IGF-I to bind to receptors was markedly decreased to $0.38 \%$ and $0.04 \%$ of normal insulin. The unprocessed insulin proreceptor was cleaved by trypsin treatment resulting in normal insulin binding. The markedly low comparative binding abilities of proinsulin and IGF-I were also restored to normal by trypsin treatment as shown in Figure 2.

\section{Competitive binding ability of mutant insulins in intact cells}

Various mutant insulins were tested for binding to the proreceptor in order to study whether markedly reduced competitive binding ability was limited to proinsulin and IGF-I. As shown in Figure 3, the competitive binding ability of $\left[\mathrm{Leu}^{\mathrm{A} 3}\right]-$, [ $\left.\mathrm{Leu}^{\mathrm{B} 24}\right]-,\left[\mathrm{Ser}^{\mathrm{B} 24}\right]$-insulin, and mini-proinsulin on ${ }^{125}$ I-insulin binding to transformed lymphocytes was the same between the patient and control subjects.

\section{$E D_{50}$ and relative binding ability of insulin analogues}

To clarify the competitive ability of various insulin analogues tested for binding study, $\mathrm{ED}_{50}$ for each of the analogues was calculated (Table 1). [Leu $\left.{ }^{\mathrm{A} 3}\right]-,\left[\mathrm{Leu}^{\mathrm{B} 24}\right]$-, [Ser ${ }^{\mathrm{B} 24}$-insulin, and mini-proinsulin showed almost the same $\mathrm{ED}_{50}$ in both the patient and control subject. However, the higher concentration of proinsulin and IGF-I was required for half maximal inhibition of ${ }^{125} \mathrm{I}$-insulin binding in the patient compared to that in the control subjects. Therefore, the larger insulin analogues with connecting peptides, i.e. proinsulin and IGF-I showed low competitive binding ability in the patient cells.

\section{Competitive binding ability of insulin analogues in lectin-purified insulin receptor preparations}

Competitive binding ability of insulin analogues was studied in solubilized receptors to examine whether the abnormal binding characteristics of proinsulin and IGF-I were retained in the proreceptor freed from plasma membranes. Insulin binding to partially purified receptor preparations was also decreased to $18 \%$ of the control value in the patient. We performed competitive binding studies of proinsulin, IGF-I, and $\left[\mathrm{Leu}^{\mathrm{B} 24}\right]$-insulin in partially lectin-purified receptor preparations. In the preparations from normal transformed lymphocytes, the competitive ability to bind to receptors was $2.50 \%, 0.20 \%$, and $16.7 \%$ of normal insulin, respectively. In the preparations from the patient's transformed lymphocytes, the competitive ability of proinsulin and IGFI to bind to receptors was also the same, i.e. $2.20 \%$, $0.20 \%$, and $18.8 \%$, respectively. This finding was in contrast to the results of binding studies in intact cells. Thus, abnormal binding characteristics were only shown in intact cells from the patient.

\section{Autophosphorylation of insulin receptor in transformed lymphocytes}

Insulin receptors from transformed lymphocytes were partially purified with WGA-agarose and autophosphorylation of the beta subunit was determined. Insulin stimulated the incorporation of ${ }^{32}$ phosphorus $\left({ }^{32} \mathrm{P}\right)$ into

Table 1. Hormone concentration required for half maximal inhibition of ${ }^{125} \mathrm{I}$-insulin binding to transformed lymphocytes

\begin{tabular}{lcr}
\hline & Control subjects & \multicolumn{1}{c}{ Patient } \\
\hline Insulin & $1.8 \pm 0.3$ & $3.0 \pm 0.5$ \\
Proinsulin & $82 \pm 13$ & $790 \pm 65^{\mathrm{a}}$ \\
IGF-I & $640 \pm 70$ & $6000<{ }^{\mathrm{a}}$ \\
{$\left[\mathrm{Leu}^{\mathrm{A} 3}\right]$ insulin } & $690 \pm 93$ & $830 \pm 116$ \\
{$\left[\mathrm{Leu}^{\mathrm{B} 24}\right]$ ]insulin } & $18 \pm 5$ & $30 \pm 7$ \\
{$\left[\mathrm{Ser}^{\mathrm{B} 24}\right]$ insulin } & $580 \pm 87$ & $625 \pm 96$ \\
Mini-proinsulin & $1500 \pm 410$ & $2400 \pm 520$ \\
\hline
\end{tabular}

Values are in $\mathrm{ng} / \mathrm{ml}$ (means $\pm \mathrm{SEM}){ }^{\mathrm{a}} P<0.01$ vs. control subjects 


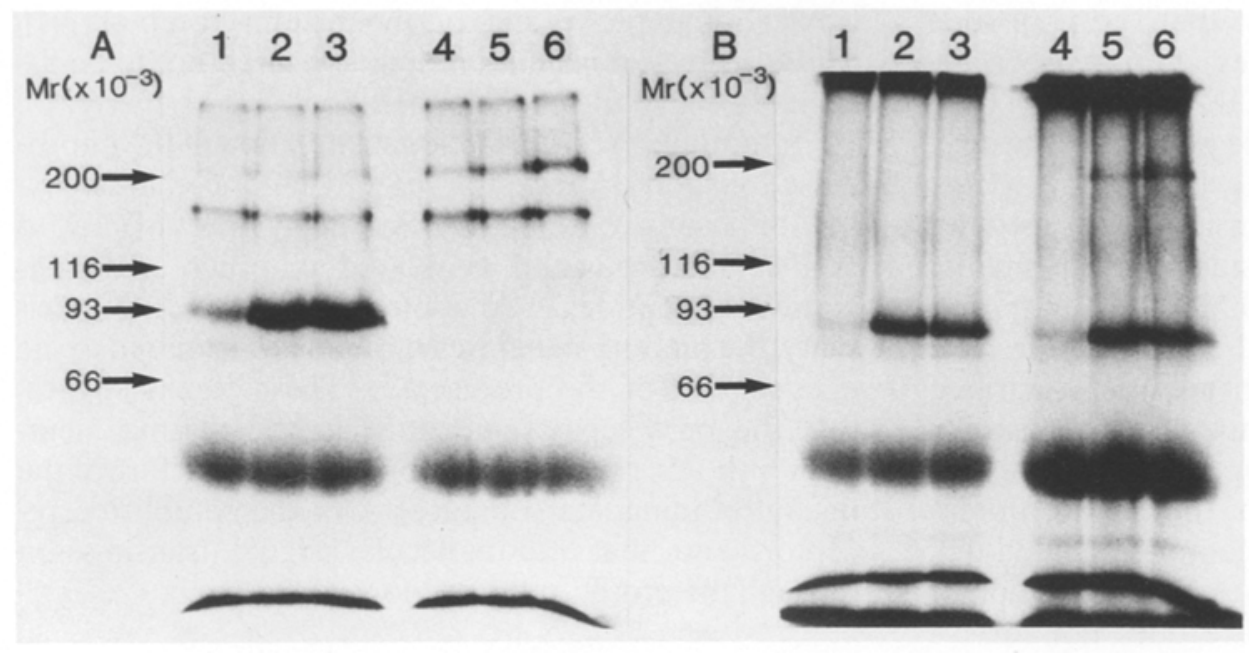

Fig.4. Insulin stimulated autophosphorylation of the beta subunit of transformed lymphocytes. Transformed lymphocytes from a normal subject (lane 1-3) and from the patient (lane 4-6) were treated with (panel B) or without (panel A) $0.025 \%$ trypsin at $25^{\circ} \mathrm{C}$ for $5 \mathrm{~min}$. The reaction was terminated by addition of a 2 -fold excess of soybean trypsin inhibitor. Then, solubilized lectin-purified preparations were preincubated with 0 (lane 1,4), 50 (lane 2,5 ), or $20,000 \mathrm{ng} / \mathrm{ml}$ (lane 3,6) of insulin. and the phosphorylation reaction was carried out at $4^{\circ} \mathrm{C}$ for $10 \mathrm{~min}$ as described in Methods. The samples were immunoprecipitated with anti-insulin receptor antibody and subjected to SDS-PAGE on a $7.5 \%$ gel under reducing conditions

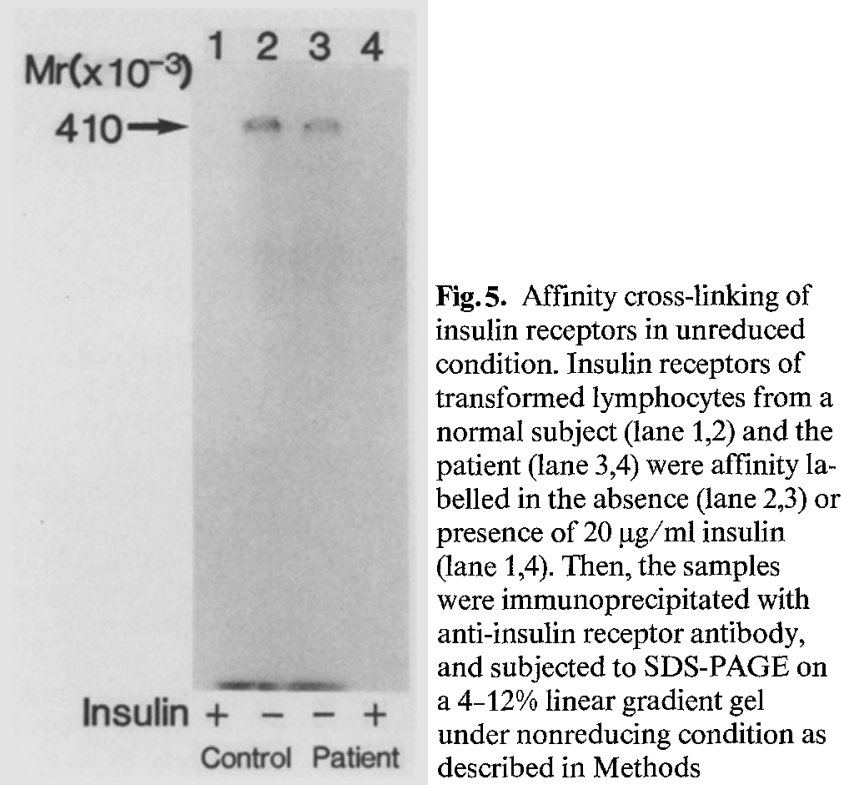

the 95 kilodalton $\mathrm{kDa}$ protein beta-subunit of normal cells in a dose-dependent manner. Insulin maximally increased the incorporation to $450 \%$ above basal incorporation. However, in the cells from the patient, ${ }^{32} \mathrm{P}$ was incorporated into a $210 \mathrm{kDa}$ protein as shown in Figure 4-A. Although the maximally stimulated incorporation to the $210 \mathrm{kDa}$ protein was $430 \%$ above basal incorporation, the net incorporation of ${ }^{32} \mathrm{P}$ per $\mathrm{mg}$ of receptor protein was decreased to $20 \%$ of that of the normal cells. Therefore, when the percent insulin-stimulated autophosphorylation over basal was plotted as a function of insulin binding activity in the partially purified preparation with WGA-agarose, there was no difference between the patient and the control subject. To examine whether phosphorylation of $95 \mathrm{kDa}$ cleaved products can be stimulated by insulin, we performed autophosphorylation on solubilized insulin receptors after $0.025 \%$ trypsin treatment. As shown in Figure 4-B, ${ }^{32} \mathrm{P}$ was incorporated into a $95 \mathrm{kDa}$ protein, and insulin stimulated the incorporation in a dose-dependent manner.

\section{Affinity cross-linking under unreduced conditions}

To examine whether oligomerization and formation of disulfide bonds occurred in the unprocessed insulin proreceptors, the proreceptor was cross-linked and electrophoresed under non-reducing conditions. Disulfidelinked oligomers, probably tetramers, were normally formed in the patient (Fig.5). Thus, the heterodimeric formation and subsequent glycosylation appeared to be normal and these abnormal proreceptors were normally transported to the plasma membrane.

\section{Discussion}

Ourselves $[28,39,31]$ and others $[30,32]$ have reported the same cases with insulin proreceptors, the differences being in the degree of decreased insulin binding to the proreceptor in transformed lymphocytes. Our studies showed $80 \%$ reduction, but Kakehi et al. reported the marked reduction to about one fifteenth of control value [30]. Although the cause of the discrepancy was unknown, slightly increased insulin binding ability of the proreceptor allowed us to analyse the functional properties of the insulin proreceptor.

Decreased insulin binding appeared to be due to decreased affinity in transformed lymphocytes from the patient. The normalized insulin binding and autophosphorylation after trypsin treatment on that proreceptor supported the notion of decreased affinity of proreceptor rather than that of decreased numbers of the receptors. The unprocessed insulin proreceptor showed decreased affinity to insulin, indicating that lack of cleavage between the alpha and beta subunit changed the three dimensional structure making binding sites less accessible to insulin. The proreceptor showed not only decreased affinity but also unique binding characteristics, namely comparatively low affinity to proinsulin and IGF-I. Whereas relative binding affinity of insulin analogues with substitution of one amino residue was normal, that of proinsulin and IGF-I was markedly 
decreased. These findings suggest that the C-peptide portion may interfere with the interaction between the proreceptor and proinsulin or IGF-I, probably by a steric hindrance effect of C-peptide residues. However, mini-proinsulin behaved normally in binding to the proreceptor, which indicated that insulins with a shorter length of C-peptide or simply insulins with a smaller size showed relatively undisturbed binding ability. The abnormal binding properties of the proreceptor were shown in whole cells, but not in partially lectin-purified insulin receptor preparations. Although, the possibility of mild hydrolysis affecting binding characteristics during the process of the disruption of the cells and preparation of the receptor cannot be completely ruled out, the finding suggests that the characteristic alteration of three-dimensional receptor structure does not survive after solubilization of insulin receptors.

The structural change of the proreceptor resulted in abnormal insulin binding, i.e. three dimensional change in binding sites. The question of how intramolecular signal transmission occurs in the proreceptor can be answered by the study of autophosphorylation. In the proreceptor, decreased autophosphorylation was proportional to the amount of insulin bound. Therefore, the signal elicited by insulin binding to the alpha subunit was transmitted normally to the beta subunit of the uncleaved insulin proreceptor. Kakehi et al. reported that the insulin-stimulated dose response curve of autophosphorylation of the proreceptor appeared to be shifted to the right [30]. However, because insulin binding was very low, this report may be difficult to interpret. The chimera receptor consisting of an intracellular portion of the epidermal growth factor (EGF) receptor and an extracellular portion of the insulin receptor possesses the ability to transmit the signal of insulin binding to elicit kinase activity of intracellular EGF receptors [39]. However, the chimera receptor consisting of an extracellular portion of the interleukin-2 receptor and an intracellular portion of the insulin receptor fails to show intramolecular signal transmission, i.e. failure of activation of kinase with interleukin-2 binding [40]. These results suggest that moderate modification of alpha- and beta-subunit interaction does not disturb the signal transmission from the binding site to kinase domain.

The mature insulin receptor is composed of two alpha- and beta-subunits linked by disulfide bonds. Since the receptor oligomerization occurs during posttranslational processing [41], changes in the tertiary structure of the proreceptor monomer may disturb dimerization, and it may be functionally relevant whether dimerization occurred in the unprocessed insulin proreceptor. The present study demonstrated that dimerization of the proreceptor occurred similarly to normal insulin receptors. Therefore, cleavage of the insulin proreceptor did not appear to be necessary to dimerize. This finding is consistent with the report that normal insulin proreceptors are able to dimerize during post- translational processing of the insulin receptor [41]. Thus, decreased insulin binding appeared not to be associated with abnormal dimerization.

In summary, conformational alteration of the unprocessed insulin proreceptor showed unique characteristics of insulin binding, i.e. markedly low affinity to IGF-I and proinsulin compared to other analogues without C-peptide. In spite of abnormal binding specificity, the binding signal was normally transmitted to the beta-subunit of the proreceptor. These results suggest that the proreceptor embedded in the plasma membranes shows a different conformational structure of the insulin binding site compared with the solubilized receptor, and that intramolecular signal transmission through the proreceptor was normal.

Acknowledgements. This work was supported in part by a research grant for intractable disease from the Ministry of Health and Welfare and a grant-in-aid from the Ministry of Education, Science, and Culture, Japan.

\section{References}

1. Kahn CR (1976) Membrane receptors for hormones and neurotransmitters. J Cell Biol 70: 261-286

2. Freychet P, Kahn CR, Roth J, Neville DM (1972) Insulin interactions with liver plasma membranes: independence of binding of the hormone and its degradation. J Biol Chem 247: 3953-3961

3. Kahn CR, Flier JS, Bar RS, Archer JA, Gorden P, Martin MM, Roth J (1976) The syndromes of insulin resistance and acanthosis nigricans. N Engl J Med 294: 739-745

4. Taylor SI, Samuels B, Roth J, Kasuga M, Hedo JA, Gorden P, Brasel DE, Pokora T, Engel RR (1982) Decreased insulin binding in cultured lymphocytes from two patients with extreme insulin resistance. J Clin Endocrinol Metab 54:919-930

5. Scarlett JA, Kolterman OG, Moore P, Saekow M, Insel J, Griffin J, Mako M, Rubenstein AH, Olefsky JM (1982) Insulin resistance and diabetes due to a genetic defect in insulin receptors. J Clin Endocrinol Metab 55: 123-132

6. Podskalny JM, Kahn CR (1982) Cell culture studies on patients with extreme insulin resistance. I. Receptor defects on cultured fibroblasts. J Clin Endocrinol Metab 54: 261-268

7. Podskalny JM, Kahn CR (1982) Cell culture studies on patients with extreme insulin resistance. II. Abnormal biological responses in cultured fibroblasts. J Clin Endocrinol Metab 54: 269-275

8. Grunberger G, Zick Y, Gorden P(1984) Defect in phosphorylation of insulin receptors in cells from an insulin-resistant patient with normal insulin binding. Science 223: 932-934

9. Grigorescu F, Flier JS, Kahn CR (1984) Defect in insulin receptor phosphorylation in erythrocytes and fibroblasts associated with severe insulin resistance. J Biol Chem 259: 15003-15006

10. Grunberger G, Comi R.J, Taylor SI, Gorden P (1984) Tyrosine kinase activity of the insulin receptor of patients with type A extreme insulin resistance: studies with circulating mononuclear cells and cultured lymphocytes. J Clin Endocrinol Metab 59: 1152-1158

11. Whittaker J, Zick Y, Roth J, Taylor SI (1985) Insulin-stimulated receptor phosphorylation appears normal in cultured Epstein-Barr virus-transformed lymphocyte cell lines derived from patients with extreme insulin resistance. J Clin Endocrinol Metab 60:381-386

12. Grigorescu F, Flier JS, Kahn CR (1986) Characterization of binding and phosphorylation defects of erythrocyte insulin receptors in the type A syndrome of insulin resistance. Diabetes 35:127-138

13. Hedo JA, Moncada VY, Taylor SI (1985) Insulin receptor biosynthesis in cultured lymphocytes from insulin-resistant patients. $\mathbf{J}$ Clin Invest $76: 2355-2361$ 
14. McElduff A, Hedo JA, Taylor SI, Roth J, Gorden P (1984) Insulin receptor degradation is accelerated in cultured lymphocytes from patients with genetic syndromes of extreme insulin resistance. J Clin Invest 74: 1366-1374

15. Kobayashi M, Olefsky JM, Elders J, Mako ME, Given BD, Schedwie HK, Fiser RH, Hintz RL, Horner JA, Rubenstein AH (1978) Insulin resistance due to a defect distal to the insulin receptor: demonstration in a patient with leprechaunism. Proc Natl Acad Sci USA $75: 3469-3473$

16. Taylor SI, Roth J, Blizzard RM, Elders MJ (1981) Qualitative abnormalities in insulin binding in a patient with extreme insulin resistance: decreased sensitivity to alterations in temperature and pH. Proc Natl Acad Sci USA 78: 7157-7161

17. Taylor SI, Hedo JA, Underhill LH, Kasuga M, Elders MJ, Roth J (1982) Extreme insulin resistance in association with abnormally high binding affinity of insulin receptors from a patient with leprechaunism: evidence for a defect intrinsic to the receptor. J Clin Endocrinol Metab 55: 1108-1113

18. Craig JW, Larner J, Locker EF, Widom B, Elders MJ (1984) Mechanisms of insulin resistance in cultured fibroblasts from a patient with leprechaunism: impaired post-binding actions of insulin and multiplication-stimulating activity. Metabolism 33: 1084-1096

19. Schilling EE, Rechler MM, Grunfeld C, Rosenberg AM (1979) Primary defect of insulin receptors in skin fibroblasts cultured from an infant with leprechaunism and insulin resistance. Proc Natl Acad Sci USA 76: $5877-5881$

20. Knight AB, Rechler MM, Romanus JA, Van Obberghen-Schilling EE, Nissley SP (1981) Stimulation of glucose incorporation and amino acid transport by insulin and an insulin-like growth factor in fibroblasts with defective insulin receptors cultured from a patient with leprechaunism. Proc Natl Acad Sci USA 78:2554-2558

21. D'Ercole AJ, Underwood LE, Groelke J, Plet A (1979) Leprechaunism: studies of the relationship among hyperinsulinism, insulin resistance, and growth retardation. J Clin Endocrinol Metab 48: 495-502

22. Kaplowitz PB, D'Ercole AJ (1982) Fibroblasts from a patient with leprechaunism are resistant to insulin, epidermal growth factor, and somatomedin C. J Clin Endocrinol Metab 55: 741-748

23. Cama A, Taylor SI (1987) Tyrosine kinase activity of insulin receptors from an insulin-resistant patient with leprechaunism. Diabetologia 30: 631-637

24. Kobayashi M, Takata Y, Sasaoka T, Shigeta Y, Goji K (1988) Fluctuation of insulin resistance in a leprechaun with a primary defect in insulin binding. J Clin Endocrinol Metab 66: 1084-1088

25. Taylor SI, Underhill LH, Hedo JA, Roth J, Rios MS, Blizzard RM (1983) Decreased insulin binding to cultured cells from a patient with the Rabson-Mendenhall syndrome: dichotomy between studies with cultured lymphocytes and cultured fibroblasts. J Clin Endocrinol Metab 56: 856-861

26. Moncada VY, Hedo JA, Serrano-Rios M, Taylor SI (1986) Insulinreceptor biosynthesis in cultured lymphocytes from an insulin-resistant patient (Rabson-Mendenhall syndrome): evidence for defect before insertion of receptor into plasma membrane. Diabetes 35: 802-807

27. Takata $Y$, Kobayashi M, Maegawa H, Watanabe N, Ishibashi O, Shigeta Y, Fujinami A (1986) A primary defect in insulin receptor in a young male patient with insulin resistance. Metabolism 35: 950-955

28. Kobayashi M, Sasaoka T, Takata Y, Hisatomi A, Shigeta Y (1988) Insulin resistance by uncleaved insulin pro-receptor: emergence of binding site by trypsin. Diabetes 37:653-656

29. Sasaoka T, Shigeta Y, Takata Y, Ishibashi O, Sugibayashi M, Hisatomi A, Kobayashi M (1989) Unprocessed insulin proreceptor in cultured fibroblasts from a patient with extreme insulin resistance. Metabolism (in press)

30. Kakehi T, Hisatomi A, Kuzuya H, Yoshimasa Y, Okamoto $M$, Yamada K, Nishimura $H$, Kosaki A, Nawata $H$, Umeda F, Ibayashi H, Imura H (1988) Defective processing of insulin-receptor precursor in cultured lymphocytes from a patient with extreme insulin resistance. J Clin Invest 81: 2020-2022

31. Kobayashi M, Sasaoka T, Takata Y, Ishibashi O, Sugibayashi M, Shigeta Y, Hisatomi A, Nakamura E, Tamaki M, Teraoka H (1988) Insulin resistance by unprocessed insulin proreceptors: point mutation at the cleavage site. Biochem Biophys Res Comm 153: $657-663$

32. Yoshimasa Y, Seino S, Whittaker J, Kakehi T, Kosaki A, Kuzuya H, Imura H, Bell GI, Steiner DF (1988) Insulin-resistant diabetes due to a point mutation that prevents insulin proreceptor processing. Science 240: 784-787

33. Kobayashi $M$, Takata $Y$, Ishibashi $O$, Sasaoka $T$, Iwasaki $M$, Shigeta Y, Inouye K (1986) Receptor binding and negative cooperativity of a mutant insulin, $\left[\mathrm{Leu}^{\mathrm{A}}\right]$-insulin. Biochem Biophys Res Comm 137: 250-257

34. Kobayashi M, Ohgaku S, Iwasaki M, Maegawa H, Shigeta $Y$, Inouye $\mathrm{K}$ (1982) Characterization of $\left[\mathrm{Leu}^{\mathrm{B}-24}\right]$ - and $\left[\mathrm{Leu}^{\mathrm{B}-25}\right]$-insulin analogues: receptor binding and biological activity. Biochem J 206: 597-603

35. Kobayashi M, Haneda M, Maegawa H, Watanabe N, Takata Y, Shigeta Y, Inouye K (1984) Receptor binding and biological activity of $\left[\mathrm{Ser}^{\mathrm{B}-24}\right]$-insulin, an abnormal mutant insulin. Biochem Biophys Res Commun 119: 49-57

36. Kobayashi M, Sasaoka T, Sugibayashi M, Iwanishi M, Shigeta Y (1989) Receptor binding and biologic activity of biosynthetic human insulin and mini-proinsulin produced by recombinant gene technology. Diabetes Res Clin Pract (in press)

37. Taylor SI, Schroer JA, Marcus-Samuels B, McElduff A, Bender TP (1984) Binding of insulin to its receptor impairs recognition by monoclonal anti-insulin antibodies. Diabetes 33: 778-784

38. Hedo JA, Kahn CR, Hayashi M, Yamada KM, Kasuga M (1983) Biosynthesis and glycosylation of the insulin receptor: evidence for a single polypeptide precursor of the two major subunits. J Biol Chem 258: 10020-10026

39. Riedel H, Dull TJ, Schlessinger J, Ullrich A (1986) A chimeric receptor allows insulin to stimulate tyrosine kinase activity of epidermal growth factor receptor. Nature 324: 68-70

40. Hatakeyama M, Doi T, Kono T, Maruyama M, Minamoto S, Mori H, Kobayashi M, Uchiyama T, Taniguchi T (1987) Transmembrane signaling of interleuken 2 receptor: conformation and function of human interleukin 2 receptor (p55)/insulin receptor chimeric molecules. J Exp Med 166: 362-375

41. Olson TS, Bamberger MJ, Lane MD (1988) Post-translational changes in tertiary and quaternary structure of the insulin proreceptor: correlation with acquisition of function. J Biol Chem 263: $7342-7351$

Received: 18 October 1938

and in revised form: 28 March 1989

Dr. M. Kobayashi

The Third Department of Medicine

Shiga University of Medical Science

Ohtsu

Shiga 520-21

Japan 